\title{
PEMIKIRAN EKONOMI SYARIAH MENURUT MUHAMMAD ABDUL MANNAN DAN MUHAMMAD BAQIR AL-SADR
}

\author{
Dewi Nur Ainiyah \\ Jl Raya Kesamben No. 265 Plumpang Tuban Jawa Timur \\ dewinurainiyah@yahoo.com
}

\author{
A. Zaim Fachri \\ Jl Jetis Kulon Gg 6 No. 11B RT 04 Wonokromo Surabaya
}

M. Zainal Abidin

Mambung 003/001 Sambang Rejo Modo Lamongan

\begin{abstract}
This article discusses Islamic economic thinking according to Muhammad Abdul Mannan and Muhammad Baqir as-Sadr. The purpose of writing this article is to find out the similarities and differences in the economic thought of Muhammad Abdul Mannan and Muhammad Baqir as-Sadr. This research is library research and is qualitative. The data were obtained through books, journal articles, and the internet, especially those discussing Islamic economics and the works of Muhammad Abdul Mannan and Muhammad Baqir as-Sadr. The data collected were analyzed comparatively. The study results conclude that Mannan and as-Sadr have the same thoughts in terms of income distribution to ensure the welfare of all elements of society in a country. The economic problem does not lie in production or the scarcity of resources, but rather due to unequal and unfair distribution due to the financial system that allows the exploitation of the strong against the weak. According to Abdul Mannan, the difference between Baqir and Mannan's thoughts is that production can combine the traditional economy and the market. At the same time, Baqir As Sadr only supports government planning and does not consider market forces. M. A. Mannan allowed private ownership, while Baqir Ash-Sadr limited private ownership to use rights only.
\end{abstract}

Keywords: Islamic economics, Muhammad Abdul Mannan, Muhammad Baqir as-Sadr, similarities, differences.

Abstrak: Artikel ini membahas tentang pemikiran ekonomi syariah menurut
Muhammad Abdul Mannan dan Muhammad Baqir as-Sadr. Tujuan penulisan artikel
ini adalah untuk mengetahui persamaan dan perbedaan pemikiran ekonomi
Muhammad Abdul Mannan dan Muhammad Baqir as-Sadr. Penelitian ini adalah
penelitian kepustakaan dan bersifat kualitatif. Data diperoleh melalui buku, artikel
jurnal dan internet, khususnya yang membahas tentang ekonomi syariah dan karya
Muhammad Abdul Mannan dan Muhammad Baqir as-Sadr. Data yang terkumpul

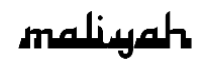

Jurnal Hukum Bisnis Islam

Volume 9, Nomor 01, Juni 2019

p-ISSN: 2088-4869/ e-ISSN: 2597-4351 
dianalisis secara komparatif. Hasil penelitian menyimpulkan bahwa Mannan dan asSadr memilik kesamaan pemikiran dalam hal pendistribusian pendapatan untuk terjaminnya kesejahteraan semua elemen masyarakat dalam sebuah negara. Persoalan ekonomi bukan terletak pada pada produksi atau faktor kelangkaan sumber daya, akan tetapi lebih dikarenakan pada persoalan distribusi yang tidak merata dan tidak adil sebagai akibat sistem ekonomi yang membolehkan eksploitasi pihak yang kuat terhadap pihak yang lemah. Perbedaan pemikiran Baqir dan Mannan di antaranya menurut Abdul Mannan produksi bisa memadukan perekonomian tradisional dan pasar, sedangkan Baqir As Sadr hanya mendukung perencanaan pemerintah dan tidak menganggap kekuatan pasar. M. A. Mannan memperbolehkan kepemilikan swasta sedangkan Baqir Ash-Sadr membatasi mengenai kepemilikan swasta tersebut hanya pada hak pakai saja.

Kata Kunci: Ekonomi syariah, Muhammad Abdul Mannan, Muhammad Baqir as-Sadr, persamaan, perbedaan.

\section{Pendahuluan}

Pada abad 16 Masehi, terjadi revolusi ilmu pengetahuan di Eropa barat yang menjadikan pamor dan kekuasaaan institusi gereja (agama Kristen) di benua tersebut menurun drastis. ${ }^{1}$ Pergerakan tersebut terjadi karena pemikiran ilmu pengetahuan seringkali berbeda dengan doktrin yang diajarkan oleh gereja. ${ }^{2}$ Untuk keluar dari kondisi tersebut maka diperlukan kajian dengan pendekatan interdisipliner dan pendekatan holistik, pendekatan yang mengintegrasikan antara kebutuhan material dan spiritual, interaksi manusia dengan interaksi alam semesta. Hal tersebut sebagaimana disarankan oleh Sismondi (1773-1842), Ruskin (1819-1900), sehingga pada saat itu mulai muncul mazhab baru, mazhab tersebut memasukkan aspek normatif, sosial dan institusi ke dalam perilaku manusia.

Hal tersebut juga berlaku pada ilmu ekonomi. Pendekatan ilmu ekonomi konvensional adalah untuk memenuhi kepentingan pribadi (self interest). ${ }^{3}$ Teori ekonomi ini dikenal

\footnotetext{
${ }^{1}$ Hanifullah, "Membangun Sistem Ekonomi Umat Berbasis Syariah," Epistemé: Jurnal Pengembangan Ilmu Keislaman 7, no. 2 (2012), 274.

${ }^{2}$ M. Nur Rianto Al-Arif, Lembaga Keuangan Syariah: Sebuah Kajian Teoretis Praktis (Bandung: Pustaka Setia, 2012), 1.

3 Syahpawi, "Kerukunan Umat Melalui Instrument Ekonomi Syariah Dalam Pembentukan Transformasi Masyarakat," Neliti.Com, 2010, https://doi.org/10.24014/trs.v2i1.427., 1.
} 
dengan ekonomi kapitalis yang diawali dengan terbitnya buku The Wealth of Nation karangan Adam Smith pada tahun $1776 .{ }^{4}$ Pandangan Smith tersebut tidak disetujui oleh pemikir-pemikir sosialis, terutama oleh karl Marx. Pemikir Sosialis lebih menginginkan agar perekonomian serba direncanakan, diatur, dan diawasi secara ketat oleh pemerintah. Sistem yang ditawarkan adalah sosialisme. Dalam sistem sosialis tidak ada perbedaan yang mencolok antara yang kaya dan yang miskin. Hal itu karena alat-alat produksi merupakan milik negara. Maka, dalam sistem sosialis dengan sendirinya tidak ada orang yang menganggur. ${ }^{5}$

Menanggapi teori ilmu konvensional tersebut, ilmuwan muslim tidak begitu saja sependapat dengan teori tersebut, tetapi mereka mengkajinya terlebih dahulu. Para ekonom muslim mengembangkan suatu ilmu ekonomi yang khas, dengan dilandasi nilai-nilai iman dan Islam yang dihayati dan diamalkan, yaitu "Ilmu Ekonomi Menurut Perspektif Islam" (Ekonomi Islami). ${ }^{6}$

\footnotetext{
${ }^{4}$ Sistem ekonomi kapitalis, sebenarnya merupakan perkembangan lebih lanjut dari perkembangan pemikiran dan perekonomian pada benua Eropa pada masa sebelumnya. Pada suatu masa, di Benua Eropa pernah ada suatu zaman dimana tidak ada pengakuan terhadap hak milik manusia, melainkan yang ada hanyalah milik Tuhan yang harus dipersembahkan kepada pemimpin agama sebagai wakil mutlak dari Tuhan. Pada zaman tersebut yang kemudian terkenal dengan sistem universalisme. Sistem ini ditegakkan atas dasar keyakinan "semua datang dari Tuhan, milik Tuhan, dan harus dikembalikan kepada Tuhan". Irawan fakhrudin Mahali Zikri, "Perpaduan Antara Pandangan Ekonomi Konvensional Dengan Ekonomi Syariah Melahirkan Sebuah Paham Ekonomi Yang Baru Dari Sebuah Sistem Yang Telah Ada," Media.Neliti.Com, n.d., https://media.neliti.com/media/publications/314794-perpaduan-antarapandangan-ekonomi-koven-c38f4607.pdf., 3.

5 Agus Waluyo, Ekonomi Konvensional VS Ekonomi Syariah Kritik Terhadap Sistem Ekonomi Kapitalis, Ekonomi Sosialis, Dan Ekonomi Islam (Yogyakarta: Ekuilibria, 2017), 4.

${ }^{6}$ Ada dua istilah yang dikenal berkaitan dengan ekonomi dalam Islam, yaitu ekonomi Islam dan ekonomi syariah. Ekonomi Islam adalah sebuah ilmu yang didasarkan atas al-Qur'an dan Hadis. Kharidatul Mudhiiah, "Analisis Sejarah Pemikiran Ekonomi Islam Masa Klasik," Iqtishadia: Jurnal Kajian Ekonomi Dan Bisnis Islam 8, no. 2 (2015), 194.
} 
Ekonomi, pada umumnya didefinisikan sebagai kajian tentang perilaku manusia dalam hubungannya dengan pemanfaatan sumber-sumber produktif yang langka untuk memproduksi barang dan jasa, serta mendistribusikannya untuk dikonsumsi. ${ }^{7}$ Secara umum, ekonomi Islam didasarkan pada lima pilar yang bersifat universal, yakni: Tauhid (Keimanan), 'adl (Keadilan), nubuwwah (Kenabian), khilafah (Pemerintahan), dan ma'ad (Hasil). ${ }^{8}$ Keberadaan sistem ekonomi Islam merupakan konsekuensi dari pandangan hidup Islam (Islamic worldview). ${ }^{9}$

Terdapat perbedaan pandangandi kalangan pemikir muslim tentang pengertian, teori dan metodologi ekonomi syariah. Para pemikir muslim tersebut terbagi dalam tiga kategori; pertama, pakar bidang fiqh sehingga pendekatan yang dilakukan adalah legalistik dan normatif; kedua, kelompok modernis yang lebih berani dalam memberikan interpretasi terhadap ajaran Islam agar dapat menjawab persoalan yang dihadapi masyarakat kini; ketiga para praktisi atau ekonom muslim yang berlatar belakang pendidikan Barat. ${ }^{10}$

Di antara para pemikir ekonomi muslim kontemporer yang pendapatnya sering dijadikan rujukan adalah Muhammad Abdul Mannan dan Muhammad Baqir as-Sadr. Keduanya memiliki konsep yang berbeda tentang ekonomi syariah. Mannan yang kelahiran Bangladesh tentu saja memiliki latar belakang yang berbeda dengan as-Sadr yang berasal dari Irak, sehingga mempengaruhi pemikiran keduanya tentang ekonomi syariah. Berdasarkan hal tersebut maka artikel ini membahas tentang ekonomi syariah menurut Muhammad Abdul Mannan dan Muhammad Baqir as-Sadr, untuk dianalisis secara komparatif.

\footnotetext{
${ }^{7}$ Choirul Huda, "Pemikiran Ekonomi Bapak Ekonomi Islam; Ibnu Khaldun," Economica: Jurnal Ekonomi Islam 4, no. 1 (2013), 104.

${ }^{8}$ Hanifullah, "Membangun Sistem Ekonomi Umat Berbasis Syariah," 281.

9 Syahpawi, "Kerukunan Umat Melalui Instrument Ekonomi Syariah Dalam Pembentukan Transformasi Masyarakat.", 6.

${ }^{10}$ Sugeng Santoso, "Sejarah Ekonomi Islam Masa Kontemporer," An-Nisbah: Jurnal Ekonomi Syariah 3, no. 1 (2016), 59.
} 


\section{Biografi Muhammad Abdul Mannan}

Muhammad Abdul Mannan lahir di Bangladesh pada 1938. Ia menikah dengan Nargis Mannan yang bergelar master di bidang ilmu politik. Mannan adalah seorang tokoh ekonomi Islam yang menganjurkan pembentukan Bank Dunia Islam (Muslim World Bank), lima tahun sebelum pembentukan sesungguhnya dari Islamic Development Bank (IDB) pada tahun 1975 di Jeddah, Arab Saudi.

Sesudah menerima gelar Master di bidang Ekonomi dari universitas Rasjshahi pada 1960, Ia bekerja di berbagai kantor ekonomi pemerintah di Pakistan di antaranya; asisten pimpinan di the Federal Planning Commission of Pakistan pada tahun 1960-an. Pada 1970 ia pindah ke Amerika Serikat dan di sana ia mendaftarkan diri di Michigan State University untuk program MA (Economics). ${ }^{11}$ Pada 1973 ia lulus program doktor dari universitas yang sama, dalam bidang minat beberapa bidang ekonomi seperti Ekonomi Pendidikan, Ekonomi Pembangunan, Hubungan Industrial dan Keuangan. Pengungkapannya atas ekonomi Barat, terutama ekonomi mainstream, adalah bukti bahwa ia memakai pendekatan mainstream di dalam pemahamannya terdapat ekonomi Islam. ${ }^{12}$

Setelah menyelesaikan program doktornya, Mannan menjadi dosen senior dan aktif mengajar di Papua New Guinea University of Tehcnology. Di sana ia juga ditunjuk sebagai pembantu dekan. Mannan mengajar di Papua Nugini dan pada 1978 ia ditunjuk sebagai Profesor di Intenational Centre For Reaserch in Islamic Universitas King Abdul Azis, di Jeddah yang kini berganti nama menjadi Centre For Research in Islamic Economics.

\footnotetext{
${ }^{11}$ Mohamed Aslam Haneef, Pemikiran Ekonomi Islam Kontemporer (Jakarta: Rajawali Press, 2010), 15-17.

12 Nukra, "Pemikiran Muhammad Abdul Mannan Tentang Pengembangan Ekonomi Islam Era Modern” (STAIN Pare Pare, 2017), 32.
} 
Selama periode tersebut, ia juga bertindak sebagai Visiting Profesor di Muslim Institute, London, dan Universitas George Town, Amerika Serikat. Melalui pengalaman akademiknya yang panjang, selanjutnya Mannan memutuskan untuk bergabung dengan Islamic Development Bank, Jeddah, di tahun 1984 dan sejak itu menjadi Ahli Ekonomi Islam Senior di sana. ${ }^{13}$

Selama 30 tahun karirnya, Mannan telah banyak berperan dalam sejumlah besar organisasi pendidikan ekonomi. Karyanya yang fenomenal Islamic Economics, Theory and Practice. ${ }^{14}$ Buku ini dipandang oleh kebanyakan mahasiswa dan sarjana ekonomi Islam sebagai 'buku teks' pertama ekonomi Islam yang mengulas tentang ekonomi Islam secara komprehensif. Buku tersebut mendapatkan pengakuan internasional dan telah diterbitkan sampai $12 \mathrm{kali}$, direvisi pada 1986, serta telah diterjemahkan kedalam bahasa Arab, Turki, Banggali, dan Malaysia dan Indonesia. Untuk sumbangannya bagi pengembangan ekonomi Islam, Mannan dianugrahi 'Higest Academic Award of Pakistan' pada 1974, yang bagi Mannan setara dengan hadiah pulitzer penulis di Eropa dan Amerika. ${ }^{15}$

Adapun hasil karya Mannan yang lain adalah: $A n$ Introduction to Applied Economics, ${ }^{16}$ Economic Problem and Planning in Pakistan, ${ }^{17}$ The Making of Islamic Economic Society: Islamic Dimensions in Economic Analsis di Kairo pada tahun 1984) dan The Frontier of Islamic Economics di India pada tahun 1984, Economic Development and Sosial Peace in Islam di UK pada tahun 1989, Management of Zakah in Modern

\footnotetext{
${ }^{13}$ Herza Ayu Menita, "Pemikiran Abdul Mannan Tentang Ekonomi Islam," AlIntaj 3, no. 1 (2017): 217.

${ }_{14}$ M.A. Mannan, Islamic Economics, Theory and Practice (Delhi: Idarah alAdabiyat, 1980).

${ }^{15}$ Rizki Syahputra, "Studi Pemikiran Ekonomi Islam Modern Prof. Muhammad Abdul Mannan, M.A., Ph.D (TelaahTerhadap Buku 'Islamic Economics; Theory and Practice')," Ecobisma (Jurnal Ekonomi, Bisnis Dan Manajemen) 2, no. 2 (2015): 93-111, https://doi.org/10.36987/ecobi.v2i2.712, 97.

${ }^{16}$ M.A. Mannan, An Introduction to Applied Economics (Dhaka, 1963).

${ }^{17}$ M.A. Mannan, Economic Problem and Planning in Pakistan (Lahore, 1968).
} 
Society IDB pada tahun 1989, Developing a System of Islamic Financial Instruments IDB pada tahun 1990, Understanding Islamic Finance: A Study of Security Market in an Islamic Framework IDB pada tahun 1993, International Economic Relation from Islamic Perspectives IDB pada tahun 1992, Structural Adjustments and Islamic Voluntary sector with special reference to Bangladesh IDB pada tahun 1995, The Impact of Single European Market on OIC Member Countries, IDB pada tahun 199), Financing Development in Islam IDB pada tahun 1996 serta beberapa artikel dan paper lainnya.

Pada 1970, ekonomi Islam berada di tahap pembentukan, berkembang dari pernyataan-pernyataan tentang prinsip ekonomi secara umum dalam Islam, hingga uraian yang lebih 'saksama' mengenai kerangka dan ciri khusus ekonomi Islam yang lain. Haruslah dicatat bahwa pada saat itu tidak ada satu universitas pun yang mengajarkan ekonomi Islam seperti sekarang, yakni suatu zaman ketika Fiqh Muamalat (hukum bisnis) masih dipandang sebagai ekonomi Islam.

Seiring dengan berlalunya waktu, ekonomi Islam telah berkembang, baik mengenai kedalamannya maupun ruang lingkupnya, ditandai oleh banyaknya buku yang ditulis orang dan diajarkannya ekonomi Islam ini di tingkat Universitas. Hal ini mendorong Mannan untuk menerbitkan dua buku lagi di tahun 1984, yakni The Making of Islamic Economic Society dan The Frontiers of Islamic Economics. Hal tersebut dapat dipandang sebagai upaya yang lebih serius dan terinci dalam menjelaskan bukunya yang pertama. ${ }^{18}$ Tak dapat disangkal bahwa Mannan telah menyumbang bagi pengembangan literatur ekonomi Islam dan karya-karyanya dianalisis oleh banyak peneliti ekonomi Islam.

\section{Pemikiran Muhammad Abdul Mannan tentang Ekonomi}

Mannan, pada dasarnya adalah sosok neo-klasik, pencerminan dari output pendidikan ekonomi konvensional

${ }^{18}$ Fahrur Ulum, "Telaah Kritis Atas Pemikiran Ekonomi Islam Abdul Mannan," Al-Qanun 12, no. 2 (2009): 441. 
yang ia terima. Mannan memilih metode elektik dalam pandangannya, dan bahkan "meminjam" gagasan dari mazhabmazhab di dalam tradisi ekonomi barat yang lebih radikal dan terisolasi. Pendekatan neo-klasik berbasis fiqh dapat digolongkan sebagai aliran mainstream dalam pemikiran ekonomi Islam. Mannan dengan ulasan yang sopan tapi keras, mengkritik segala usaha untuk membersihkan kapitalisme dan ekonomi neo-klasik dengan cara yang bersifat "kosmetik" dan dengan cara keras pula ia membela peranan pemerintah dalam perekonomian. ${ }^{19}$

Ekonomi Islam merupakan sebuah ilmu pengetahuan sosial yang mempelajari masalah-masalah ekonomi rakyat dengan berpedoman kepada nilai-nilai 'ilahiyah' yaitu ajaran Islam yang paripurna (QS. al-Mâidah / 5:3). Definisi yang dikemukakan oleh M. A Mannan meletakkan ekonomi Islam ke dalam sebuah disiplin keilmuan. Mannan menyetujui bahwa masalah ekonomi adanya sumber daya yang terbatas dan dihadapkan pada keinginan manusia yang tidak terbatas. Misal: permintaan dan penawaran beras di seluruh dunia berada pada titik equilibrium, dibandingkan dengan tempat dan waktu tertentu terjadi kelangkaan sumber daya, contoh negara di Ethiopia dan Bangladesh lebih langka dibandingkan dengan Thailand.

Mannan mempunyai dalil dalam surat Al-Baqarah ayat 155:

"Dan sesungguhnya akan kami berikan cobaan kepadamu, dengan sedikit ketakutan, kelaparan, kekurangan harta, jiwa dan buah-buahan dan berikanlah berita gembira kepada orang-orang yang sabar".

Sabda Nabi Muhammad SAW, bahwa manusia tidak akan puas walaupun diberi emas satu lembah, dia akan minta emas dua lembah, bila diberi dua lembah ia akan meminta tiga lembah dan seterusnya sampai ia masuk kubur.

\footnotetext{
${ }^{19}$ Asdar Yusup, "Paradigma Kontemporer Ekonomi Islam (Muh. Abdul Mannan versus Syed Nawab Haedir Naqvi)," Hunafa: Jurnal Studia Islamika 11, no. 2 (2014), 228-229.
} 
Seluruh kegiatan ekonomi dalam Islam bukanlah sebuah tujuan akhir dari kehidupan melainkan hanya merupakan sarana untuk mencapai tujuan yang tinggi, yaitu falah. ${ }^{20}$

Berikut dibahas pemikiran Mannan tentang konsumsi, produksi dan distribusi:

1. Konsumsi

Dalam aspek konsumsi, Muhammad Abdul Mannan menyatakan bahwa konsumsi merupakan bagian yang sangat penting dalam kajian ekonomi Islam. Baginya kegiatan konsumsi tidak hanya sekedar bagaimana menggunakan hasil produksi. Lebih dari itu, konsumsi Islami harus dapat menciptakan sebuah distribusi pendapatan dan kekayaan (ekonomi) yang adil. Keberadaan segala bentuk pelarangan konsumsi barang mewah dalam Islam tanpa disertai redistribusi kekayaan dan pendapatan tidak akan sama sekali menyelesaikan masalah-masalah ekonomi. Sehingga menurut Mannan konsumsi adalah permintaan sedangkan produksi adalah penawaran, kebutuhan konsumen yang kini dan yang telah diperhitungkan sebelumnya merupakan insentif pokok bagi kegiatankegiatan ekonominya sendiri.

Dalam suatu masyarakat primitif, konsumsi sangat sederhana karena kebutuhannya juga sangat sederhana, tetapi peradaban modern telah menghancurkan kesederhanaan akan kebutuhan-kebutuhan ini. Peradaban materialistik dunia barat memperoleh kesenangan khusus dengan membuat bermacam-macam kebutuhan, kesejahteraan seseorang pun hampir diukur berdasarkan macam-macam sifat kebutuhan yang diusahakan untuk dapat terpenuhi dengan upaya khusus.

2. Distribusi

\footnotetext{
${ }^{20}$ Falah berasal dari bahasa arab dari kata kerja aflaha-yuflihu yang berarti kesuksesan, kemulian atau kemenangan. Istilah falah berarti kesejahteraan holistik dan seimbang antara dimensi material dan spritual, individual-sosial dan kesejahteraan di kehidupan duniawi dan akhirat. Rahmat Ilyas, "Etika Konsumsi Dalam Perspektif Ekonomi Islam," AT-TAWASSUTH: Jurnal Ekonomi Islam 1, no. 1 (2016): 165.
} 
Dalam aspek distribusi, Mannan memandang bahwa keterlibatan Islam yang bersifat pragmatis dan realistis bagi si miskin adalah sedemikian tulusnya sehingga distribusi pendapatan merupakan pusat berputarnya pola dan organisasi produksi didalam suatu negara Islam. Ia tambahkan bahwa dalam produksi pertimbangan distributiflah yang harus memengaruhi prioritas produksi barang dan jasa, dan dengan demikian ia juga menjadi indikator konsumsi.

Berbeda dari para ekonom Islam lainnya yang menyatakan distribusi sebagai basis fundamental bagi alokasi sumber daya, mannan menyatakan distribusi kekayaan tergantung pada kepemilikan orang yang tidak seragam. Di sini keadilan, "keadilan mutlak mempersyaratkan bahwa imbalan juga seharusnya berbeda, dan bahwa sebagian orang memiliki lebih banyak dari yang lain, itu adalah hal yang wajar saja, asalkan keadilan manusia ditegakkan dengan prinsip kesempatan yang sama bagi semua orang. Jadi, seseorang tetap dapat memiliki surplus penerimaannya asal ia telah menunaikan semua kewajibannya".

Oleh karena itu, ketidakmerataan itu sah-sah saja, dan menurut kaidah Mannan tentang 'keadilan mutlak' disebabkan oleh sumbangan yang berbeda. Namun ketidakmerataan ini pulalah, terutama yang ekstrem, yang menjadi perhatian utama ekonomi Islam. Lebih jauh Mannan menyatakan bahwa "dalam suatu perekonomian Islam, inti masalah tidak terletak pada harga yang ditawarkan oleh pasar, melainkan pada ketidakmerataan distribusi pendapatan. Itulah yang paling penting di dalam ekonomi Islam". Masalah distribusi di dalam ekonomi neoklasik, menurut Mannan, muncul karena kegagalannya dalam menyikapi isu-isu yang berhubungan dengan kepemilikan sumber daya.

Meskipun Mannan berbicara demikian banyak mengenai pentingnya distribusi dan perlunya penetapan pedoman tentang siapa memiliki apa, namun, ia tidak membahas 
kepemilikan sumber daya kecuali mengenai tanah. Menurut Mannan, secara umum tanah dapat dimiliki melalui kerja seseorang. Tetapi oleh karena Mannan mengakui kepemilikan oleh non penggarap, maka pemilik juga dibolehkan baik untuk menyewa maupun berbagi hasil tanaman, sekalipun ia setuju dengan yang disebut terakhir.

3. produksi

Mannan melihat produksi sebagai penciptaan guna. Agar dapat dipandang sebagai utility, dan dengan demikian meningkatkan kesejahteraan ekonomi, maka barang dan jasa yang diproduksi itu haruslah hanya yang dibolehkan dan menguntungkan (yakni halal dan baik) menurut islam saja. Baginya, "konsep Islammengenai kesejahteraan berisi peningkatan produksi yang baik saja, melalui pemanfaatan sumber-sumber (manusia dan materiil) secara maksimal maupun melalui partisipasi jumlah penduduk maksimal di dalam proses produksi". Penekanannya pada kualitas, kuatitas, maksimisasi dan partisipasi di dalam proses produksi menjadikan firm memiliki fungsi yang berbeda di dalam sistem ekonomi. Firm tidak lagi dipandang hanya sebagai pemasok komoditas melainan juga sebagai penjaga bersama (yakni bersama pemerintah) bagi kesejahteraan ekonomi dan masyrakat.

Bahkan tujuan firm juga bukan hanya maksimalisasi laba saja, melainkan juga harus memerhatikan moral, sosial, dan kendala-kendala institusional. Bagi Mannan, akibat gabungan dari profite motive, kekerabatan dan tanggung jawab sosial, dipandu dengan dorongan moral sajalah yang akan mengacu proses produkstif dan distributif. Keseragaman tujuan, yang merupakan tujuan yang hendak dicapai itu, haruslah berupa maksimalisasi laba dipadu dengan semua kerangka nilai dalam Islam.

Di dalam sistem ekonomi Islam, produksi dilakukan untuk memadukan perekonomian tradisional dan pasar. Tujuan ganda ini, menurut Mannan, menjadi batas antara mekanisme pasar dan hal-hal yang tak boleh tidak dari perekonomian komando, serta seluruh isu teoritis yang 
terkait dengan kedua tujuan tersebut. Surplus produksi diperlukan di dalam ekonomi Islam untuk mewujudkan persediaan yang tepat bagi generasi sekarang dan yang akan datang. Tidak seperti sistem lain (kapitalisme dan sosialisme) yang menekankan baik kepada individu maupun kelompok/Negara, Mannan melihat individu melalui kelompok sebagai pusat kegiatan ekonomi di dalam sistem ekonomi Islam. Apa yang sebenarnya dimaksudkan dan bagaimana hal itu dioperasionalkan, tidaklah diterangkan dengan cukup oleh Mannan.

Proses produksi menurut Mannan adalah usaha kerja sama antara para anggota masyarakat untuk menghasilkan barang dan jasa bagi kesejahteraan ekonomi mereka. Nilai persaudaraan, jika diaplikasikan ke dalam lingkungan ekonomi, akan melahirkan lingkungan kerja sama, bukan persaingan, penyebaran lebih luas atau sosialisasi sarana produksi, bukan konsentrasi maupun ekploitasi sumber daya alam dan manusia lebih lanjut. Dalam membuat keputusan teknis, maka efisiensi, seperti yang dipahami di dalam kerangka neoklasik, tidak akan mengambil tempat utama lagi. Sebaliknya, perhatian akan lebih tercurah kepada pertengahan antara efisiensi produktif dan keadilan. Seperti yang teah disampaikan sebelumnya, definisi Mannan tentang efisiensi berisi pertimbangan-pertimbangan keadilan. Barang tidak akan dihasilkan dengan mempertimbangkan permintaan efektif, tetapi kebutuhan efektif yakni kebutuhan yang didefinisikan menurut norma dan nilai-nilai Islam.

Mannan setuju dengan para ahli ekonomi fisiokrat dan klasik mengenai keberadaan hukum alam yang bersifat independen, namun dapat diselami oleh akal, seperti the law of diminishing return. Namun, ia membuang pandangan fisiokrat mengenai produktivitas, termasuk di dalam analisisnya, pembagian faktor produksi neoklasik seperti yang disebutkan di depan. Harus juga dicatat bahwa ia menentang sosialisasi lengkap sarana produksi seperti yang ada di dalam sosialisme, 
karena hal itu, dalam pandangannya, akan bertentangan dengan hak-hak asasi manusia.

Akhirnya, Mannan membicarakan produksi sebagai suatu proses sosial. Dalam proses sosial ini, sekali lagi ia menekankan perlunya kriteria distributif untuk menetapkan keputusan produksi, tidak seperti pendekatan neoklasik yang memandang keduanya secara terpisah. Persis seperti ia memperkenalkan konsep kebutuhan efektif untuk menggantikan permintaan efektif, ia meletakkan teori penawaran berdasar kapasitas potensial menurutnya, akan mengakomodasi pemberian kebutuhan dasar kepada semua anggota masyarakat, khususnya golongan miskin. Di sini, produsen tidak hanya melakukan reaksi atas harga pasar melainkan juga atas perencanaan nasional untuk memenuhi kebutuhan dasar manusia tanpa peduli kepada permintaan pasar. Ia setuju dengan gagasan pembagian kerja dan spesialisasi untuk memproduksi secara efisien dan adil, namun secara konstan menekankan perlunya humanisasi proses produksi. Mengenai hal ini orang hanya dapat menduga artiya sebagai hubungan buruh-majikan, dan penerapan nilai-nilai moral/etika islam di dalam proses produksi.

\section{Biografi Muhammad Baqir As-Sadr}

Asy Syahid Muhammad Baqir AsSadr dilahirkan di Kadhimiyeh, Baghdad pada 1935, sebagai keturunan dari sebuah keluarga sarjana dan intelektual Islam Syi'ah yang termasyhur, wajar saja Sadr mengikuti langkah kaki mereka. ${ }^{21}$

Muhammad Baqir Ash-Shadr kehilangan ayahnya, dan kemudian diasuh oleh ibunya yang religius dan kakak lakilakinya, Ismail, yang juga seorang mujtahid kenamaan di Irak. Muhammad Baqir Ash-Shadr menunjukkan tanda-tanda kejeniusan sejak usia kanak-kanak. Pada usia sepuluh tahun, beliau berceramah tentang sejarah Islam, dan juga tentang beberapa aspek lain tentang kultur Islam. Beliau mampu menangkap isu-isu teologis yang sulit dan bahkan tanpa

\footnotetext{
${ }^{21}$ Haneef, Pemikiran Ekonomi Islam Kontemporer, 131.
} 
bantuan seorang guru pun. Ketika usia sebelas tahun, beliau mengambil studi logika dan menulis sebuah buku yang mengkritik para filosof.

Pada usia tiga belas tahun, kakaknya mengajarkan kepadanya 'Ushul 'ilm al-fiqh (asas-asas ilmu tentang prinsipprinsip hukum Islam yang terdiri atas Al-Qur'an, Hadis, Ijma' dan Qiyas). Pada usia sekitar enam belas tahun, beliau pergi ke Najaf untuk menuntut pendidikan yang lebih baik dalam berbagai cabang ilmu-ilmu Islami. Sekitar empat tahun kemudian, beliau menulis sebuah ensiklopedi tentang 'Ushul, Ghayat Al-Fikr fi Al-'Ushul (pemikiran puncak dalam 'Ushul).

Ia memilih untuk menuntut pengajaran Islam tradisional di hauzah atau sekolah tradisional di Iraq, dan di situ ia belajar fiqh, ushul, dan teologi. Ia amat menonjol dalam prestasi intelektualnya, sehingga pada umur 20 tahun telah memperoleh derajat mujtahid mutlaq, dan selanjutnya meningkat lagi ke tingkat otoritas tertinggi marja (otoritas pembeda). Otoritas intelektual dan spiritual di dalam tradisi Islam tersebut juga terwujud di dalam tulisan-tulisan Sadr, dan di dalam karyanya Iqtishaduna (ekonomi kita) ia menunjukkan metodologi "pernyataan tegas independen, tetapi memenuhi syarat"

Sekalipun memiliki latar belakang tradisional, Sadr tidak pernah terpisah dari isu-isu kontemporer. Minat intelektualnya yang tajam mendorongnya untuk secara kritis mempelajari filsafat kontemporer, ekonomi, sosiologi, sejarah, dan hukum. Seperti Taleghani, ia adalah seorang alim yang aktif. Secara terus menerus ia menyuarakan pandangan-pandangannya mengenai kondisi kaum muslimin dan membicarakan keinginan untuk merdeka, tidak saja kalangan politik, namun dari pemikiran dan gagasan. Kondisi di Iraq mendorongnya untuk mendirikan Hizb ad Da'wah al Islamiyah (partai dakwah Islam), yakni sebuah partai yang menyatukan para pimpinan agama dan kaum muda, yang terutama sekali dimaksudkan untuk melawan gelombang sosialisme Ba'ats yang mengambil kekuasaan politik pada 1958. Karyanya Falsafatuna (filsafat kita) dan kemudian Iqtishaduna, memberikan suatu kritik 
komparatif terhadap kapitalisme maupun sosialisme, dan pada saat yang sama menggambarkan pandangan dunia Islam bersama dengan garis-garis besar sistem ekonomi Islam.

Di seluruh tulisannya, ia berusaha untuk membangkitkan kembali tradisi Islam bagi kaum muslimin modern, terutama kaum mudanya. Secara luas ia mengutip keterangan Al-Qur'an, Hadis dan para imam Syi'ah, yang seluruhnya itu mencerminkan latar belakang hukum tradisionalnya. Namun demikian, sering kali pula ia mengutip penafsiran atau membuat penafsiran sendiri mengenai masalah dan situasi kontemporer. Usaha yang dituangkannya di dalam Iqtishaduna sedikit banyak menyuarakan suatu filsafat ekonomi kepada koleksi hukum legal, dan hal itu mencerminkan kemampuannya member kehidupan kepada hukum-hukum yang tampak mubazir. Ditulis pada 1960 an Iqtishaduna haruslah dipandang sebagi sebuah analisis komperehensif dan perbandingan sistem ekonomi dari perspektif Islam, dan itu masih dipakai sebagai referensi para ahli pada tahun 90 an.

Di tahun 1982, setelah bekerja bertahun-tahun, pemerintah Iran menerjemahkan karyanya itu ke dalam bahasa Inggris. Sayangnya, terjemahan itu telah memperlakukan karya asli Sadr secara tidak adil. Meskipun demikian, hal itu malah menjadikan pemikiran Sadr dibaca orang secara lebih luas. Pendekatan 'ekonomi hukum'nya telah mendapatkannya suatu posisi sebagai pemikir Islam terdepan dan oleh karenanya kita masukkan ke dalam analisis kita ini.

\section{Pemikiran Muhammad Baqir As Sadr tentang Ekonomi}

Muhammad Baqir As-Sadr dalam bukunya "Iqthishaduna" (ekonomi kita), Mazhab ini berpendapat bahwa ilmu ekonomi tidak pernah sama dengan Islam, ekonomi tetap ekonomi, dan Islam tetap Islam. Keduanya tidak akan dapat disatukan, karena keduanya berasal dari filosofi yang kontradiktif, yang satu anti Islam, yang lainnya Islam. ${ }^{22}$

22 (Baqir Al Hasani dan Abbas Mirakhor, tt : 21-23) dalam bukunya "The Consep of Iqthishad". 
Mazhab ini juga berbeda pendapat mengenai adanya keinginan manusia yang tidak terbatas, sementara sumber daya yang tersedia untuk memuaskan keinginan manusia tersebut jumlahnya terbatas. Mazhab ini menolak pernyataan Surat Al Qomar ayat 49 yang artinya: "Sesungguhnya kami menciptakan segala sesuatu menurut ukuran".

Dengan demikian karena segala sesuatu itu sudah terukur dengan sempurna, sebenarnya Allah telah memberikan sumber daya yang cukup bagi manusia seluruh dunia. Dalam pendapat ini bahwa keinginan manusia itu tidak terbatas ditolak. Contoh manusia akan berhenti minum, jika dahaganya sudah terpuaskan. Oleh karena itu Mazhab ini berkesimpulan bahwa keinginan yang tidak terbatas itu tidak benar, sebab pada kenyataan keinginan manusia itu terbatas.

Dalam buku lain dijelaskan bahwa menurut Mazhab ini bahwa dalam mempelajari ilmu ekonomi harus dilihat dari dua aspek, yaitu aspek philosophy of economics atau normative economics dan aspek positif economics. Mazhab ini memandang adanya perbedaan antara ilmu ekonomi dengan ideology Islam. Akibatnya adalah keduanya tidak akan bisa bertemu. Istilah ekonomi Islam adalah istilah yang kurang tepat sebab ada ketidaksesuaian antara definisi ilmu ekonomi dengan ideologi Islam tersebut. Pandangan demikian didasarkan pengertian dari ilmu ekonomi yang menyatakan bahwa masalah ekonomi timbul karena adanya masalah kelangkaan sumber daya ekonomi (scarcity) dengan sumber daya manusia yang tak terbatas. $^{23}$

Tentunya hal ini bertentangan dengan Al Qur'an Surat Al Furqon ayat 2 yang menjamin keseimbangan antara kebutuhan manusia dengan sumber daya yang tersedia. Yang artinya:

"Yang kepunyaan Nya lah kerajaan langit dan bumi, dan Dia tidak mempunyai anak, dan tidak ada sekutu baginya dalam kekuasaan Nya, dan Dia telah menciptakan segala sesuatu, dan Dia menetapkan ukuran-ukurannya dengan serapi-rapinya."

${ }^{23}$ Chamid, Jejak Langkah Sejarah Pemikiran Ekonomi Islam, 407. 
Menurut teori ekonomi, masalah ekonomi muncul karena adanya keinginan manusia yang tidak terbatas sedangkan sumber daya yang tersedia terbatas. Mazhab Iqtishaduna menolak hal ini karena dalam Islam tidak pernah dikenal adanya sumber daya yang terbatas.

Secara garis besar pemikiran Baqir As Sadr ada tiga macam, yaitu pelarangan riba, distribusi dan produksi:

1. Pelarangan riba dan implementasi zakat

Sadr tidak membahas riba seperti yang barangkali orang harapkan. Penafsirannya terhadap riba hanyalah terbatas pada pembahasan mengenai bunga dan modal uang. Adapun mengenai implementasi zakat, Sadr memandangnya sebagai kewajiban negara. Bersama dengan zakat, ia juga membahas khums (yang sebagaimana zakat juga merupakan fixed taxes), fay dan anfal, demikian juga pajak-pajak lain yang dapat dipungut dan dibelanjakan untuk maksud-maksud pengentasan kemiskinan dan untuk menciptakan 'keseimbangan sosial' yang telah disebutkan di depan. Yang menarik dari pemikiran Sadr adalah perhatiannya yang eksklusif terhadap kemiskinan relatif. Argumennya untuk menentukan tingkat kemiskinan absolut atau seperti yang dinyatakan, tingkat kemiskinan tetap, tidak akan mengarah ke suatu keseimbangan living standart antara si kaya dan si miskin adalah lemah.

Para ahli muslim setuju bahwa harus ada suatu standart of living dasar yang dapat dianggap sebagai stanfdar minimal yang diperlukan oleh setiap orang. Menetapkan standar ini tidak akan mencegah kita dari terus mempersempit celah standart living seperti yang diusulkan oleh Sadr. Karena itu, banyak yang tidak meneriman pemikiran Sadr ini karena jika diterima, akan menyebabkan sebuah negara yang amat miskin yang tidak mampu memenuhi kebutuhan dasar kepada siapapun juga, akan dipandang sebagai negara yang ditimpa kemiskinan, dengan alasan sederhana bahwa setiap orang memiliki standart of living yang sama.

2. Distribusi 
Distribusi (bersama dengan hak kepemilikan) menempati sebagian besar pemikiran ekonomi Sadr. Hampir sepertiga bukunya iqtishaduna dipakai untuk membahas distribusi dan hak kepemilikan. Sadr membagi pembahasannya menjadi dua pembagian, yakni distribusi sebelum produksi dan sesudah produksi.

Sebagai seorang ahli hukum tradisional, penjelasan Sadr yang terinci mengenai hal itu didasarkan pada ajaran atau hukum yang berhubungan dengan kepemilikan. Disini akan dijelaskan 2 macam distribusi, yaitu:

a. Distribusi sebelum produksi

Distribusi tanah dan sumber daya alam lain diistilahkan sebagai kekayaan primer. Seperti para ahli yang lain, Sadr mencela kapitalisme karena mengabaikan isu ini, yang menurutnya menentukan produksi (sampai batas tertentu) dan dengan sendirinya juga menentukan distribusi sesudah produksi. Dalam membahas status kepemilikan sumber daya alam, Sadr membagi sumber daya alam menjadi empat kategori, yakni tanah, bahan mentah (sumber daya alam) di dalam tanah, air, dan sumber daya lain (prosuk laut, sungai, dan buah-buahan). Ada beberapa hal yang perlu disebutkan:

1) Kepemilikan oleh negara adalah jenis kepemilikan yang paling sering, meskipun hak pakai dapat diperoleh dari negara

2) Kepemilikan swasta hanya diizinkan di dalam sejumlah kecil keadaan:

a) Tanah yang digarap di wilayah penduduk yang menerima Islam secara sukarela (melalui dakwah).

b) Jika ditetapkan di dalam perjanjian.

c) Mineral tersembunyi yang memerlukan usaha untuk mendapatkannya dan hanya sejauh mineral yang digali saja serta di seluas area pertambangan saja.

d) Sumber daya lain, yakni melalui kerja atau tenaga kerja orang, seperti penangkapan burung, penebangan kayu, dan sebagainya. 
3) Kepemilikan swasta hanyalah terbatas pada hak pakai, prioritas penggunaan dan hak untuk mencegah orang lain memakai barang yang sedang dimiliki oleh orang lain.

4) Untuk mineral dan air, individu diperkenankan untuk menggunakan apa yang mereka perlukan.

Ada dua hal yang dapat dikemukakan berkenaan dengan pandangan Sadr mengenai kepemilikan dan hubungannya dengan distributive rights. Pertama adalah masalah relevansi. Kategorisasi Sadr didasarkan pada masa lampau, masa-masa perluasan Islam, sehingga orang mungkin saja mengatakan bahwa kategori itu ketinggalan zaman.

Sekalipun Sadr tidak menyebut secara eksplisit bahwa luas tanah harus dibatasi, namun ia menyebutkan dua hal:

1) Tanah swasta akan tetap menjadi tanah swasta selama ada tenaga kerja yang terlibat, yakni selama tanah itu digarap

2) Hak pakai diberikan sesuai dengan kemauan dan kapasitas mengerjakan.

b. Distribusi setelah produksi

Sadr mengawali pembicaraan dengan menyatakan bahwa Islam tidak menganggap semua faktor produksi (ataupun pemiliknya) itu sama sederajat, yakni orang yang melakukan prosuksi (pekerja) adalah pemilik riil dari barang yang dihasilkan. Selanjutnya pekerja itu bertanggung jawab untuk membayar uang kompensasi bagi faktor produksi lain yang digunakan di dalam proses produksi. Sadr merasa bahwa pandangan ini telah melakukan manusia sebagai majikan, bukan budak produksi. Melanjutkan argumen ini, Sadr menyatakan bahwa seorang kapitalis tidak diperblehkan untuk memiliki produk pekerja yang ia upah. Dengan kata lain tenaga kerja ekonomi langsung merupakan syarat perlu bagi kepemilikan produk.

Pandangannya mengenai kekayaan primer muncul ketika ia memberikan kepemilikan pada pihak pertama 
yang menggarap sumber daya alam - misalnya orang yang menghidupkan tanah mati- untuk memilikinya dalam pengertian pemilikan prioritas dan hak untuk mencegah orang lain menggunakannya. Selanjutnya, jika ia ingin mengupah orang untuk menggarap tanah itu, ia masih tetap memiliki tanah tersebut karena tenaga kerja awal yang ia kerjakan ketika menghidupkan tanah mati tersebut. Di lain pihak, pekerja memiliki produk tanah itu karena memang dialah yang mengerjakan, dan membayar kompensasi kepada pemilik tanah jika kepemilikan atas tanah itu masih ada. Kompensasi tersebut dapat berbentuk sewa tetap atau bagi hasil (jika pemilik tanah menyediakan benih/pupuk atau peralatan)

Namun, Sadr membedakan antara mengerjakan sumber daya alam milik orang lain (seperti contoh diatas) dan bekerja pada produk pekerja milik orang lain, misalnya pekerja yang memintal benang dari wool milik seorang pengembala, dalam hal ini, produk (benang) milik pengembala dan pekerja itulah yang akan menerima kompensasi.

Dengan pandangan mengenai pekerja prioritas itu, Sadr kemudian menuliskan daftar imbalan bagi masing-masing faktor produksi.

1) Tenaga kerja - upah atau bagian laba.

2) Tanah - sewa (atau bagi hasil tanam).

3) Modal uang - bagian laba.

4) Alat/ modal fisik - upah/kompensasi.

Tenaga kerja diberi pilihan antara imbalan tetap (upah) dan imbalan variable (bagian laba). Sewa tanah hanya diperbolehkan jika pemilik tanah telah menanamkan tenaganya sejak awal, misalnya tenaga menghidupkan tanah mati. Sadr juga mempertahankan pandangan umum yang membolehkan transaksi seperti mudharabah, muzara'ah, musaqat, dan jualah. Namun, yang terlarang adalah membeli murah dan menjual mahal tanpa adanya kontribusi atau kerja bagi suatu produk, atau mengambil 
sewa tanah dan kemudian menyewakannya kepada orang lain lebih mahal.

Pandangan diatas menunjukkan dengan jelas bahwa Sadr melihat imbalan yang sah atau halal itu adalah imbalan yang didasarkan pada kerja. Namun, selain kerja, ada lagi sumber distributive rights di dalam ekonomi Islam, yakni kebutuhan. Oleh karena itu, ada perbedaan antara kapasitas dan kemampuan antar individu, maka ketimpangan distribusi pendapatan adalah suatu hal yang wajar saja. Sebagian mungkin menerima hasil yang tidak cukup sementara yang lain malah tidak menerima apaapa sama sekali. Situasi seperti ini menyebabkan mereka mempunyai distributive rights, dan Negara memainkan peran yang amat besar dalam menciptakan keseimbangan sosial. Islam meletakkan tekanan pada living standart yang lebih tinggi melalui pelarangan tindakan berlebihan, dan pada saat yang sama mengangkat mereka yang berada ditingkat bawah dengan memberikan sistem jaminan sosial. Redistribusi juga memainkan peranannya dan berbagai macam pajak juga diterima oleh Sadr (zakat, anfal, fay'). Sadr juga melihat bahwa negara memainkan peran dinamis dalam mengimplementasikan kebijakan untuk menghadapi tantangan masyarakat kontemporer

3. Teori Produksi

Sadr mengklasifikasi dua aspek yang mendasari terjadinya aktivitas produksi. Pertama adalah aspek obyektif atau aspek ilmiah yang berhubungan dengan sisi teknis dan ekonomis yang terdiri atas sarana-sarana yang digunakan, kekayaan alam yang diolah dan kerja yang dilakukan dalam aktivitas produksi. Aspek ini berusaha untuk menjawab pertanyaan dasar mengenai what, how, dan whom (The three fundamental economic problem). Yang kedua yaitu aspek subyektif. Terdiri atas motif psikologis, tujuan yang hendak dicapai lewat aktifitas produksi, dan evaluasi aktivitas produksi menurut konsepsi keadilan yang dianut.

Negara mempunyai tugas untuk merencanakan dan membimbing kegiatan ekonomi sejalan dengan ajaran yang 
terdapat di dalam Al-Qur'an, sunnah, dan para imam. Oleh karenanya, ia mendukung perencanaan pemerintah dan tidak menganggap kekuatan pasar sebagai sesuatu yang keramat. Produksi, atau pemanfaatan karunia Allah, adalah kewajiban yang harus dijalankan dengan penuh tanggung jawab. Dalam rangka memberikan pandangan yang sehat mengenai dan bimbingan dalam produksi Islam menurut Sadr, memiliki dua cabang strategi.

a. Strategi Doktrin/intelektual

Manusia termotivasi untuk bekerja karena bekerja dipandang sebagai ibadah jika dilaksanakan dengan pemahaman dan niat seperti yang dinyatakan di dalam Al-Qur'an. Membiarkan sumber menganggur, melakukan pengeluaran mubazir ataupun produksi barang-barang haram adalah terlarang, dan seorang Islamic man haruslah peka terhadap hal ini.

b. Strategi legislative

Legislatif dapat mendukung doktrin dengan membolehkan Negara menjalankan dan meregulasi kegiatan ekonomi. Ada banyak contoh ekonomi yang disampaikan Sadr:

1) Tanah menganggur dapat disita oleh negara dan di redistribusikan kepada mereka yang mau dan mampu menggarapnya.

2) Larangan Islam terhadap hima' yakni memiliki tanah dengan paksa.

3) Prinsip tak ada kerja tak ada hasil.

Selain itu menurut Sadr sumber asli produksi terdiri dari tiga kelompok yakni, alam, modal, dan kerja. Adapun sumber alam yang digunakan untuk produksi dibagi menjadi tanah, substansi-substansi primer, dan air.

\section{Analisis Komparatif terhadap Pemikiran Ekonomi Muhammad Abdul Mannan dan Muhammad Baqir As-Sadr}

Perbedaan pemikiran Baqir dan Mannan di antaranya Menurut Abdul Mannan dalam sistem ekonomi Islam, produksi dilakukan baik untuk digunakan maupun dipertukarkan, dan 
Pemikiran Ekonomi Syariah Menurut Muhammad Abdul...

dengan demikian berarti memadukan perekonomian tradisional dan pasar. Sedangkan Baqir As Sadr hanya mendukung perencanaan pemerintah dan tidak menganggap kekuatan pasar. Pemikiran Abdul Mannan lebih kepada melangsungkan kelangsungan hidup mudharabah tidak hanya tataran nasional melainkan juga internasional sedangkan Baqir menekankan penuntasan kemiskinan dan menciptakan keseimbangan sosial. Menurut Mannan dalam hal distribusi, ia melihat bahwa dirinya berbeda dari para ekonom Islam lainnya, karena menyatakan distribusi sebagai basis fundamental bagi alokasi sumber daya, sehingga inti permasalahan tidak terletak pada harga yang ditawarkan pasar melainkan pada ketidakmerataan distribusi pendapatan namun distribusi menurut Baqir ia membagi menjadi dua yakni distribusi sebelum produksi yang didalamnya membahas tentang status kepemilikan sumber daya alam yang dalam teorinya tenaga kerja adalah satu-satunya sumber bagi terjadinya hak milik dalam hal sumber daya alam dan dalam distribusi sesudah produksi menurutnya ketimpangan distribusi pendapatan adalah suatu hal yang wajar saja karena ada perbedaan kapasitas dan kemampuan antar individu.

Mannan memiliki anggapan bahwa perbedaan utama antara ilmu ekonomi konvensional dengan ekonomi Islam adalah dalam hal cara mencapai tujuan. Ia menyetujui pandangan konvensional bahwa masalah ekonomi muncul karena adanya keterbatasan sumber daya ekonomi untuk memenuhi kebutuhan manusia yang tidak terbatas. Jadi pandangan Mannan berbeda dengan pandangan Baqir As Sadr menurut Mannan secara parsial ataupun lokal sangat mungkin terjadi kelangkaan sumber daya ekonomi, meskipun secara keseluruhan (alam semesta) terjadi keseimbangan. Misalnya di Afghanistan atau Irak terjadi kekurangan sumber daya ekonomi. Di sisi lain manusia pada dasarnya juga memiliki keinginan yang tidak terbatas, justru dengan ajaran Islamlah kemudian manusia dituntut untuk mengendalikan 
keinginannya, sebab jika keinginannya lepas kendali maka akan menyengsarakan kehidupan manusia sendiri. ${ }^{24}$

M.A. Mannan berpendapat bahwa ahli ekonomi Islam dan modern saling mendukung konsepsi tentang problem ekonomi, yang meliputi: kelangkaan sumber daya alam (scarce source) dan keinginan-keinginan yang tidak terbatas (unlimited wants). Pendapat M.A. Mannan sejalan dengan pandangan M. Baqir AshSadr. Menurutnya, "persoalan ekonomi bukan terletak pada pada produksi atau faktor kelangkaan sumber daya, akan tetapi lebih dikarenakan pada persoalan distribusi yang tidak merata dan tidak adil sebagai akibat sistem ekonomi yang membolehkan eksploitasi pihak yang kuat terhadap pihak yang lemah. Timbulnya problem ekonomi ini disebabkan oleh dua alasan yaitu: ketidakadilan manusia dalam kesalahan distribusi sumber daya alam, dan adanya eksploitasi manusia pada alam yang berlebihan.

Terkait pengelolaan SDA M.A. Mannan memperbolehkan kepemilikan swasta dan senantiasa menjaga hak individual ini sepanjang individu tersebut tidak menyalahgunakan kepercayaan (dalam memiliki itu) dengan mengeksploitasi pihak lain. Sedangkan, Baqir Ash-Sadr membatasi mengenai kepemilikan swasta tersebut hanya pada hak pakai saja, sehingga kekuasaan tertinggi dipegang oleh negara atau ulil amri, sehingga keadilan tersebut haruslah merata dan tidak ada ketimpangan. Produksi menurut Baqir ash-sadr adalah suatu proses dinamis, mengubah dengan pengembangan ilmu pengetahuan dan teknologi. Sedangkan distribusi sebagai bagian dari sistem sosial, yaitu total hubungan antar sistem sosial yang memancar dari kebutuhan orang dan bukan dari gaya produksi. Maka dari itu, Baqir Ash-Shadr percaya untuk mempertahankan satu sistem sosial tunggal (mencakup distribusi) bermacam-macam alat atau format produksi, tetapi menolak pandangan Marxis, bahwa masyarakat terdiri dari potensi yang berlawanan dalam bentuk kelas.

${ }^{24}$ Nur Chamid, Jejak Langkah Sejarah Pemikiran Ekonomi Islam (Yogyakarta: Pustaka Pelajar, 2010), 407. 
Persamaan dari dua tokoh ekonomi Islam ini (M Abdul Mannan dan M Baqir Ash-Shadr) dalam hal pendistribusian pendapatan untuk terjaminnya kesejahteraan semua elemen masyarakat dalam sebuah negara, dalam hal keadilan untuk mengakses sarana-sarana publik. Serta menghilangkan kelaskelas kapitalis untuk mencegah segala bentuk penyimpangan dalam pengelolaan ekonomi negara. ${ }^{25}$

\section{Penutup}

Berdasarkan pemaparan di atas maka dapat disimpulkan bahwa Abdul Mannan dan Baqir As-Sadr merupakan ahli ekonomi Islam besar bagi pengembangan ekonomi Islam. Mereka memiliki persamaan dan perbedaan dalam pemikiran ekonomi Islam. Perbedaan pemikiran Baqir dan Mannan di antaranya Menurut Abdul Mannan dalam sistem ekonomi Islam, produksi dilakukan baik untuk digunakan maupun dipertukarkan, dan dengan demikian berarti memadukan perekonomian tradisional dan pasar. Sedangkan Baqir As Sadr hanya mendukung perencanaan pemerintah dan tidak menganggap kekuatan pasar. Pemikiran Abdul Mannan lebih kepada melangsungkan kelangsungan hidup mudharabah tidak hanya tataran nasional melainkan juga internasional sedangkan Baqir menekankan penuntasan kemiskinan dan menciptakan keseimbangan sosial. M. A. Mannan memperbolehkan kepemilikan swastas sedangkan, Baqir AshSadr membatasi mengenai kepemilikan swasta tersebut hanya pada hak pakai saja.

Pendapat M. A. Mannan sejalan dengan pandangan M. Baqir AshSadr bahwa persoalan ekonomi bukan terletak pada pada produksi atau faktor kelangkaan sumber daya, akan tetapi lebih dikarenakan pada persoalan distribusi yang tidak merata dan tidak adil sebagai akibat sistem ekonomi yang

${ }^{25}$ Siska Lis Sulistiani, "Distribusi Dalam Ekonomi Islam Untuk Pembangunan Negara Menurut Baqir Ash-Shadr Dan M Abdul Mannan,” Amwaluna: Jurnal Ekonomi Dan Keuangan Syariah 1, no. 1 (2017): 132-33, https://doi.org/10.29313/amwaluna.v1i1.2104. 
membolehkan eksploitasi pihak yang kuat terhadap pihak yang lemah. Selain itu mereka sepakat dalam hal pendistribusian pendapatan untuk terjaminnya kesejahteraan semua elemen masyarakat dalam sebuah negara, dalam hal keadilan untuk mengakses sarana-sarana publik. Serta menghilangkan kelaskelas kapitalis untuk mencegah segala bentuk penyimpangan dalam pengelolaan ekonomi negara.

\section{Daftar Pustaka}

Al-Arif, M. Nur Rianto. Lembaga Keuangan Syariah: Sebuah Kajian Teoretis Praktis. Bandung: Pustaka Setia, 2012.

Chamid, Nur. Jejak Langkah Sejarah Pemikiran Ekonomi Islam. Yogyakarta: Pustaka Pelajar, 2010.

Haneef, Mohamed Aslam. Pemikiran Ekonomi Islam Kontemporer. Jakarta: Rajawali Press, 2010.

Hanifullah. "Membangun Sistem Ekonomi Umat Berbasis Syariah." Epistemé: Jurnal Pengembangan Ilmu Keislaman 7, no. 2 (2012).

Huda, Choirul. "Pemikiran Ekonomi Bapak Ekonomi Islam; Ibnu Khaldun.” Economica: Jurnal Ekonomi Islam 4, no. 1 (2013). Ilyas, Rahmat. "Etika Konsumsi Dalam Perspektif Ekonomi Islam." AT-TAWASSUTH: Jurnal Ekonomi Islam 1, no. 1 (2016): $152-72$. https://doi.org/http://dx.doi.org/10.30821/ajei.v1i1.367. Mannan, M.A. An Introduction to Applied Economics. Dhaka, 1963.

- - Economic Problem and Planning in Pakistan. Lahore, 1968.

- - - Islamic Economics, Theory and Practice. Delhi: Idarah al-Adabiyat, 1980.

Menita, Herza Ayu. "Pemikiran Abdul Mannan Tentang Ekonomi Islam." Al-Intaj 3, no. 1 (2017): 216-38.

Mudhiiah, Kharidatul. "Analisis Sejarah Pemikiran Ekonomi Islam Masa Klasik." Iqtishadia: Jurnal Kajian Ekonomi Dan Bisnis Islam 8, no. 2 (2015).

Nukra. "Pemikiran Muhammad Abdul Mannan Tentang Pengembangan Ekonomi Islam Era Modern." STAIN Pare 
Pare, 2017.

Santoso, Sugeng. "Sejarah Ekonomi Islam Masa Kontemporer." An-Nisbah: Jurnal Ekonomi Syariah 3, no. 1 (2016).

Sulistiani, Siska Lis. "Distribusi Dalam Ekonomi Islam Untuk Pembangunan Negara Menurut Baqir Ash-Shadr Dan M Abdul Mannan." Amwaluna: Jurnal Ekonomi Dan Keuangan Syariah 1, no. 1 (2017): 131-48. https://doi.org/10.29313/amwaluna.v1i1.2104.

Syahpawi. "Kerukunan Umat Melalui Instrument Ekonomi Syariah Dalam Pembentukan Transformasi Masyarakat." Neliti.Com, 2010. https://doi.org/10.24014/trs.v2i1.427.

Syahputra, Rizki. "Studi Pemikiran Ekonomi Islam Modern Prof. Muhammad Abdul Mannan, M.A., Ph.D (TelaahTerhadap Buku 'Islamic Economics; Theory and Practice')." Ecobisma (Jurnal Ekonomi, Bisnis Dan Manajemen) 2, no. 2 (2015): 93-111. https://doi.org/10.36987/ecobi.v2i2.712.

Ulum, Fahrur. "Telaah Kritis Atas Pemikiran Ekonomi Islam Abdul Mannan." Al-Qanun 12, no. 2 (2009): 436-61.

Waluyo, Agus. Ekonomi Konvensional VS Ekonomi Syariah Kritik Terhadap Sistem Ekonomi Kapitalis, Ekonomi Sosialis, Dan Ekonomi Islam. Yogyakarta: Ekuilibria, 2017.

Yusup, Asdar. "Paradigma Kontemporer Ekonomi Islam (Muh. Abdul Mannan versus Syed Nawab Haedir Naqvi)." Hunafa: Jurnal Studia Islamika 11, no. 2 (2014).

Zikri, Irawan fakhrudin Mahali. "Perpaduan Antara Pandangan Ekonomi Konvensional Dengan Ekonomi Syariah Melahirkan Sebuah Paham Ekonomi Yang Baru Dari Sebuah Sistem Yang Telah Ada." Media.Neliti.Com, n.d. https://media.neliti.com/media/publications/314794perpaduan-antara-pandangan-ekonomi-kovenc38f4607.pdf. 